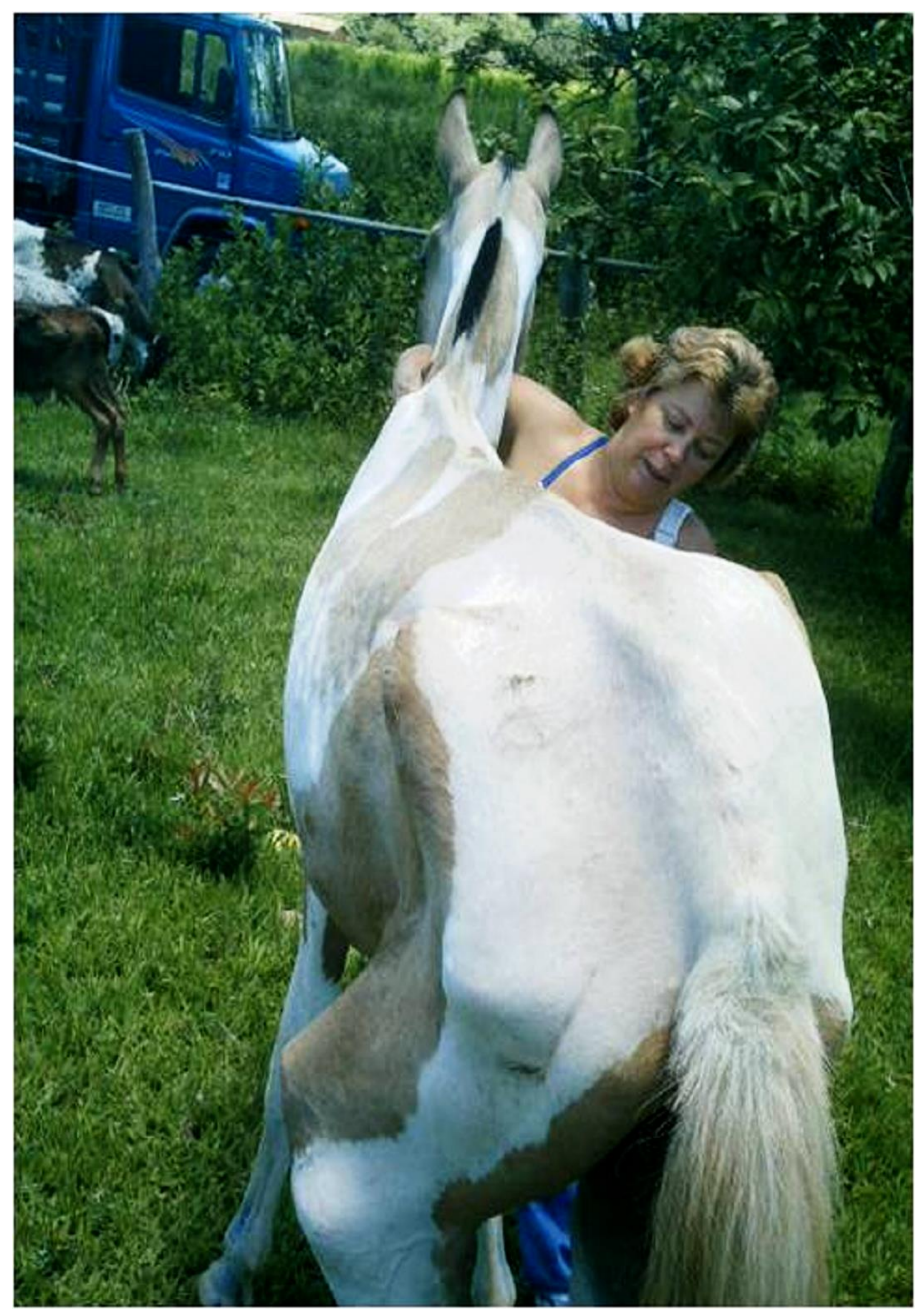

Vera Macedo junto com um dos seus cavalos

\title{
MEIA BAILARINA
}

\section{Maria Luísa Silveira da Rocha}

Maria Luísa Silveira da Rocha, psicóloga pela Universidade Federal de Minas Gerais. Contista no site Anjos de Prata (www.anjosdeprata.com.br) desde 2007. Premiações: $3^{\circ}$ lugar no Concurso Literário da ASTTTER, na categoria contos, em 2008, com o texto "Índios e Cicatrizes".

Hoje de manhã eu estava em casa resolvendo os problemas novos que me foram impostos pela condição de síndica do prédio. Havia procurado telefones de firmas de impermeabilização nas páginas amarelas de imprestáveis catálogos, fizera contas do saldo que seria possível dispor no final do mês e me aborrecera com intermináveis arrumações na pasta de documentos e atas. 
Resolvi parar um pouco e fui preparar um café. Já passava das nove horas e uma vontade súbita de comer mais um pedaço de pão acompanhado de um café coado na hora me fez levantar da cadeira e acender o fogo para ferver a água. Meus pensamentos ainda estavam misturando as contas do condomínio com as minhas pessoais e me deparei com uma situação meio sombria. Parecia que o meu dinheiro seria insuficiente até o final do mês: contas demais, novamente. Fiquei aflita e impaciente. Provavelmente teria que usar mais uma vez o cheque especial.

Mas o que fazer? O jeito seria cortar os gastos o máximo possível e limitar as compras de supermercado e as saídas à noite.

O telefone tocou e me assustei. Havia acabado de coar o café e tomado uns dois goles, apreciando o calor extremo da bebida escura. Tenho enorme preguiça de atender telefones e fui fazêlo com muita má vontade.

- Alô!

- Alô!

- Queria falar com a Soninha.

- É ela. Pode falar.

- Aqui é a Vera. Tudo bom?

Não respondi. Quem diabos seria esta Vera? Não me lembrava de nenhuma...

- É O seguinte: vou bem direto ao assunto porque eu tenho pouco tempo e preciso demais de sua ajuda. Ontem eu estava na favela do Pau Comeu, onde fui entregar umas roupas para o bazar da creche e, de repente, no meio de uma viela, avistei uma égua em um estado lastimável. Meus olhos se fixaram nos dela e tive a certeza de que precisava salvá-la. Ela estava com as patas traseiras muito machucadas e me pareceu fraquinha e debilitada. Estava um farrapo só.

Dei uma resmungada e saiu algo assim: - Sei, ah. Já sabia que era a Vera amiga do Franklin, tão ou mais louca por animais do que ele e igualmente capaz de tudo para salválos. Faziam o que fosse preciso sem pensar no que viria depois. O Franklin, por exemplo, desce dentro do rio Arrudas quantas vezes for necessário para fazer resgate de cães e outros bichos que pessoas covardes jogam lá naquela imundície para morrer lentamente, de inanição, de fratura e, sobretudo, de tristeza diante de tamanha ignomínia. A Vera continuou a falar:

-Eu vi o pedido de socorro nos seus olhos desesperados e não pude negar ajuda. Precisava tirá-la dali ou ela iria morrer logo ... Falei com o seu dono - um carroceiro miserável e sujo 
- que estava interessada em adquiri-la. Ele riu de modo debochado e me falou que ela já não estava valendo nada, não adiantava mais nem bater nela que a desgraçada não queria puxar carroça. Insisti e ele espertamente me pediu mil e duzentos reais. Recusei e a negociação prosseguiu até chegar nos quinhentos reais. Ele aceitou e fiz o cheque. Mas só tenho trezentos reais na conta e só recebo na terça-feira. Por isto, gostaria de saber se você poderia me emprestar duzentos reais. Prometo que te pago tudo direitinho.

Fiquei calada. Que merda. Tinha acabado de fazer as contas e o dinheiro estava limitado às despesas da casa. Estava chateada justamente com esta possibilidade e aparece a Vera me pedindo duzentos reais. Se ainda fosse menos, uns vinte... Duzentos reais é muito dinheiro.

Mas não sei resistir a este tipo de apelo. Definitivamente não posso falar não.

E, friamente, concordei com o empréstimo.

- Tá bom. Vou até a loteria fazer o depósito.

- Deus te pague e que São Francisco te ilumine.

- Amém.

Saí e fui fazer o que precisava ser feito. Às dez horas e sete minutos o dinheiro estava na conta dela e às dez horas e quinze minutos o carroceiro retirava o dinheiro na boca do caixa, como viria a saber depois.

À tarde, mais ou menos às quatro horas, quando eu bebia um chá preto bem quente com biscoitos de polvilho, o telefone tocou. Saí esbravejando e fui atender. Era a Vera. - Alô, Soninha. Queria te agradecer mais uma vez e contar que deu tudo certo.

E relatou que a gerente lhe avisara que o homem retirara o dinheiro logo que o banco abriu e que, se não fosse a minha presteza, o cheque iria voltar e suas dívidas se multiplicariam como uma bola de neve. Fiquei sem graça. Conhecia o trabalho da Vera em prol dos animais necessitados, que consumia todas as suas reservas, principalmente as financeiras.

Ela me convidou pra ir conhecer a égua, que já estava instalada em um sítio após ter sido examinada por uma veterinária. A danadinha estava bem - o seu problema era mesmo fome e maus-tratos. Parece que havia a possibilidade de estar prenhe. Já pensou ? Um potrinho a caminho... Vera, com certo orgulho que me pareceu maternal, estava aliviada e radiante. E descreveu o novo cenário em que a égua passaria a viver o resto de seus dias. Disse também que o animal comia sem parar capim, cenouras e biscoitos. Eu não sabia que cavalos comiam biscoito. Perguntei a ela como a bichinha se chamava. Vera respondeu: 
Achei a coisa mais linda do mundo o nome e perguntei o porquê. Ela explicou que era justamente por causa de suas pernas tortas e magras. E falou e falou, sem se preocupar com impulsos excedentes. E me confidenciou que a Bailarina era o quinto cavalo que ela livrara das mãos de carroceiros cruéis e exploradores.

Fiquei envergonhada e me senti pequena, insignificante mesmo no meu mundinho de cafés e chás fumegantes, biscoitos delicados tardes mornas. E a interrompi, num rompante: - Vera, não precisa mais depositar o dinheiro na minha conta na terça-feira. Eu vou te dar esta ajuda. Ela ficou muito agradecida e me convidou novamente pra ir conhecer a Bailarina. Desliguei o telefone e fiquei rindo baixinho: acabara de adquirir meia égua; na verdade, era quase meia égua. Meu marido e filhos chegaram à noite e não lhes contei a história real. Disse apenas que estava atuando em um novo ramo: negócios com equinos. Eles me olharam com estranheza, achando que eu estava escondendo leite e com dinheiro sobrando. Eles sabem que lido bem com dinheiro, sou boa administradora do vil metal e faço o tinhoso render e esticar até onde eu quero. Até hoje eles estão desconfiados... Estava devendo cinquenta reais para o meu marido e ele, como sempre pouco ligado nestas questões, não queria aceitar a quantia. Resolvi incluílo no negócio e partilhar a minha nova aquisição. E brinquei, dizendo que ele era dono de um décimo da Bailarina. Se quiser, pode escolher a cauda... Ele riu feliz e já deve estar preparando uma linda canção pra ela: Baila, baila, Bailarina... Aquela noite foi longa e especial. Sabia que merecia uma comemoração e resolvi beber meia garrafa de vinho. Estava excitada com tudo que acontecera e não queria saber de ir dormir. Fiquei quieta na escuridão, saboreando o vinho devagarinho, deixando aquela sensação de bem-estar e felicidade manter afastado o sono que se aproximava de mansinho, insistente, e que custou a me derrubar. E quando isto aconteceu, bons sonhos me embalaram e pude, finalmente, conhecer a Bailarina, livre e feliz, me olhando de frente, bem dentro dos meus olhos vermelhos e embriagados. E me lembrei de Amadeo Modigliani: quando conhecer tua alma, eu pintarei teus olhos.

P.S. Dedico este trabalho à magnífica e corajosa Vera Macedo, a Verdadeira.

Março de 2009 . 